\title{
STRATIGRAPHICAL STUDIES ON LAKE IIDESJÄRVI SEDIMENTS. PART II. GEOCHEMICAL AND MINERALOGICAL CHARACTERISTICS OF THE SEDIMENTARY SEQUENCE
}

\author{
ANTTI VUORINEN, RAIMO UUSINOKA AND PENTTI ALHONEN
}

\begin{abstract}
VUORINEN, ANTTI, UUSINOKA, RAIMO AND ALHONEN, PENTTI 1983: Stratigraphical studies on Lake Iidesjärvi sediments. Part II. Geochemical and mineralogical characteristics of the sedimentary sequence. Bull. Geol. Soc. Finland 55, 2, 141-156.

This paper presents data on the geochemical and mineralogical characteristics of a core pertinent to the limnological history of Lake Iidesjärvi in the town of Tampere (S. Finland). The geochronology together with the pollen and diatom stratigraphy of its sediment sequence have been given earlier (Alhonen 1981). The new palaeolimnological results from Lake Iidesjärvi show the anthropogenic enrichment of heavy metals such as $\mathrm{Cd}, \mathrm{Cu}, \mathrm{Hg}, \mathrm{Pb}$ and $\mathrm{Zn}$ in the topmost sulphide-banded clay-gyttja of its lithostratigraphy. This cultural eutrophication was interpreted by studying extraction kinetics of $\mathrm{Fe}, \mathrm{Si}, \mathrm{Ca}, \mathrm{Mg}, \mathrm{K}, \mathrm{Cu}$ and $\mathrm{Zn}$ using ammonium oxalate and hydroxylammonium chloride plus acetic acid solutions. The productivity history of Lake Iidesjärvi was studied by the determinations of ignition loss, sedimentary chlorophyll and sedimentary humus. The mineralogical composition of the lithostratigraphy shows that the presence of clay minerals, particularly vermiculite, with extractable $\mathrm{Mg}, \mathrm{Fe}$ and $\mathrm{Na}$ has probably led to minero-eutrophy of Lake Iidesjärvi since its isolation from the Ancylus Lake in agreement with the results of the diatom stratigraphy.
\end{abstract}

Key words: clay minerals, lithostratigraphy, geochemistry, sediments.

Antti Vuorinen and Pentti Alhonen: Department of Geology, University of Helsinki, Snellmaninkatu 5, SF-00170 Helsinki 17.

Raimo Uusinoka: Tampere University of Technology, EngineeringGeological Laboratory, P.O. Box 527, SF-33101 Tampere 10.

\section{Introduction}

Earlier studies (Alhonen 1981) show that Lake Iidesjärvi in the town of Tampere (South Finland) has been limnologically more or less productive since its isolation from the Ancylus Lake. This conclusion is based on the diatom stratigraphy of the main core, which was taken with a Livingstone sampler from the deepest part of the lake (Fig. 1). Lake Iidesjärvi has also been affected by intensive land use and settlement of the town of Tampere. This is reflected in the lithostratigraphy as the forma- 


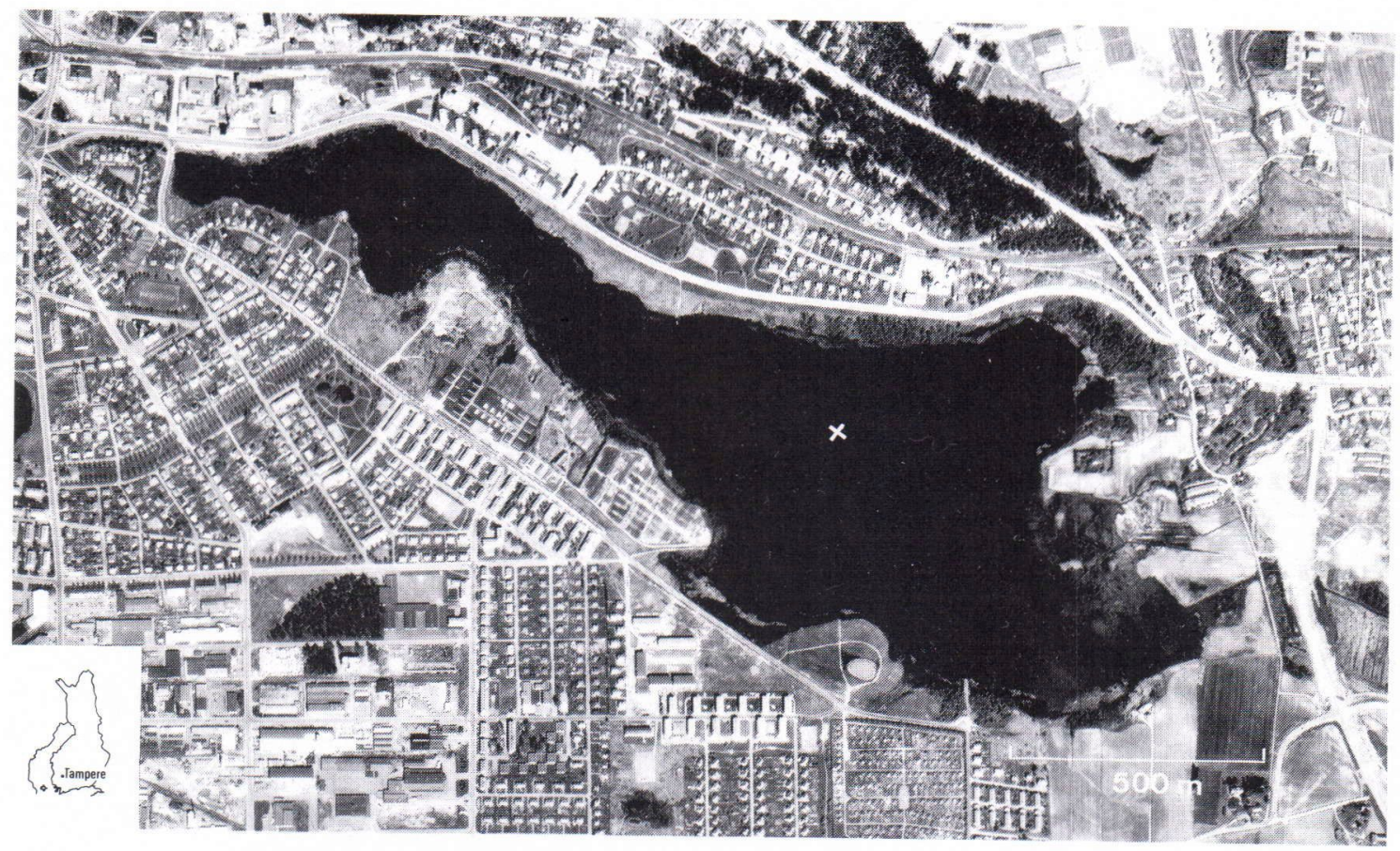

Fig. 1. Air photograph 77156:93 (212311) of Lake Iidesjärvi showing the sampling site (published with permission of the General Survey Office). The scale is corrected.

tion of sulphide bands in the topmost claygyttja indicating the dynamics of cultural eutrophication (see e.g. Alhonen 1979). Limnochemically, oxygen deficiencies are therefore common because of the high nutrient level caused by sewage. The limnological status of Lake Iidesjärvi and of its geological environment has been reported earlier by Alhonen (1981, pp. 98-99).

In this report we present data on the mineral and geochemical characteristics of the bottom sediments pertinent to the limnological history of Lake Iidesjärvi. The purpose is thus to obtain information on the nature of the sedimentary material in relation to the geology of the drainage basin, the major source of the sedimented material being the drainage of the lake rather than the organic matter synthesized in its water
(Mackereth 1966). The analyses were done on the core (Fig. 2) described by Alhonen in 1981 (p. 100 and Fig. 3). The uppermost $40 \mathrm{~cm}$ were analysed in greater detail, because they were deposited during the pollution development of Lake Iidesjärvi.

\section{Analytical methods}

Geochemistry

The homogenized subsamples were dried for 24 hours at $90^{\circ} \mathrm{C}$ for acid digestion and ignition loss determinations. The samples were air-dried at room temperature for extraction procedures. The loss on ignition was determined by igniting the samples for 1 hour at $800^{\circ} \mathrm{C}$. 


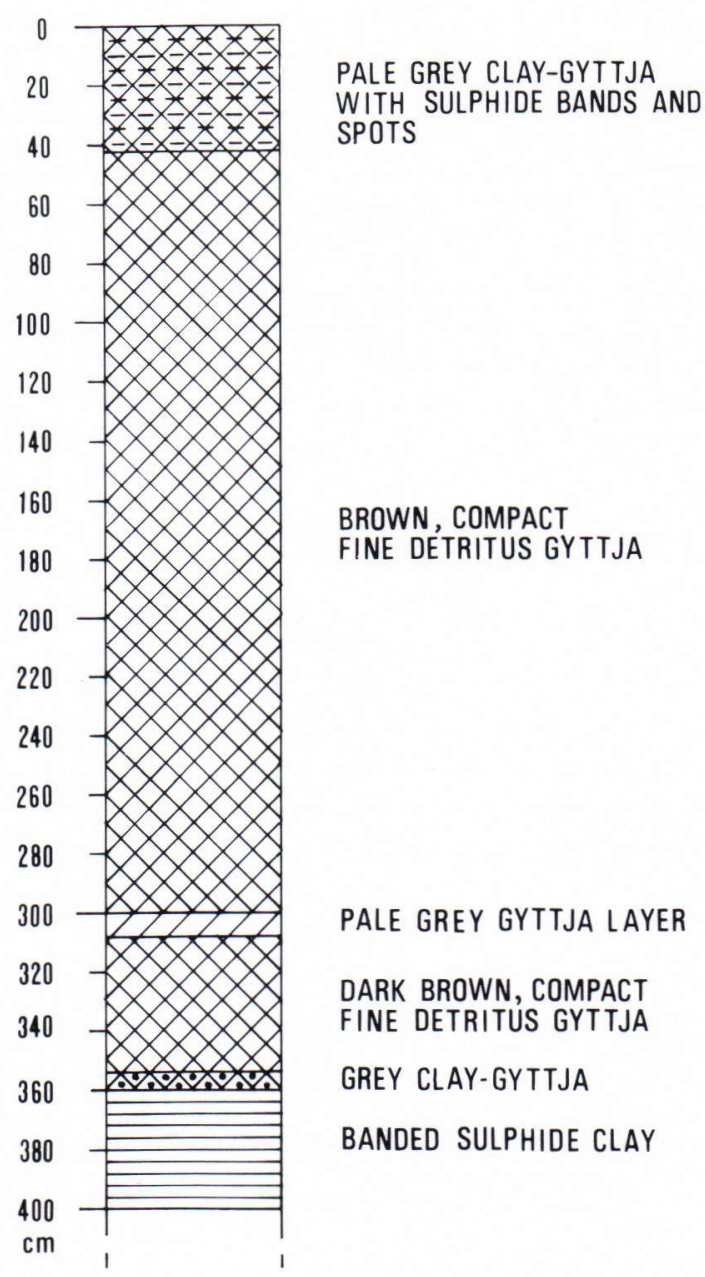

Fig. 2. Lithostratigraphy of the investigated core (Alhonen 1981, Fig. 3).
About $1 \mathrm{~g}$ of sample was weighed into a Teflon dish and $5 \mathrm{ml}$ of $\mathrm{HCl}(12 \mathrm{M}), 5 \mathrm{ml}$ of $\mathrm{HNO}_{3}(15.5 \mathrm{M})$ and $0.4 \mathrm{ml}$ of $\mathrm{HClO}_{4}(16.6 \mathrm{M})$ were added. The samples were digested on a warm plate at $90^{\circ} \mathrm{C}$ for 12 hours. The acids were then evaporated until $\mathrm{HClO}_{4}$ vapours developed at $160^{\circ} \mathrm{C}$. The samples were cooled, $2 \mathrm{ml}$ of $\mathrm{HCl}(12 \mathrm{M})$ were added and the salts were dissolved by boiling for 5 minutes. The liquid was removed with pure water and transferred to flasks $10 \mathrm{ml}$ in volume for analysis. A number of samples were extracted for organically bound elements with sodium hypochlorite solution, for sedimentary chlorophyll with acetone, and for humic substances with $\mathrm{NaOH}$ solution (Table 1). Elemental forms and binding of elements were studied by subjecting the samples to a selective sequential extraction procedure using ammonium acetate solution $\left(\mathrm{NH}_{4} \mathrm{Ac}\right)$, solution of hydroxylammonium chloride ( $\mathrm{HXl}$ ), and a mixture of HXl-HAc. Solution kinetics were studied using $\mathrm{NH}_{4} \mathrm{Ac}$ and $\mathrm{HXl}-\mathrm{HAc}$ extraction and varying the time intervals (Table 1).

The acid-digested samples were analysed for $\mathrm{Al}, \mathrm{Ca}, \mathrm{Cd}, \mathrm{Cu}, \mathrm{Fe}, \mathrm{Hg}, \mathrm{K}, \mathrm{Li}, \mathrm{Mg}, \mathrm{Pb}$, $\mathrm{Rb}, \mathrm{Zn}, \mathrm{PO}_{4}$ and sedimentary humus (Table 2 ). The $\mathrm{NH}_{4} \mathrm{Ac}$ and HXl-HAc exctract supernatants were centrifuged at different time intervals and analysed for $\mathrm{Ca}, \mathrm{Cu}, \mathrm{Fe}, \mathrm{K}, \mathrm{Mg}$,

Table 1. Extraction conditions.

\begin{tabular}{|c|c|c|c|c|c|}
\hline EXTRACT & $\begin{array}{l}\text { CONCENTRA- } \\
\text { TION }\end{array}$ & $\mathrm{pH}$ & $\begin{array}{c}\text { SOLID/ } \\
\text { SOLUTION }\end{array}$ & $\mathrm{T}$ & TIME \\
\hline $\mathrm{HClO}$ & $\begin{array}{l}\text { active } \mathrm{Cl} 3.5 \% \\
\text { in } 0.1 \mathrm{M} \mathrm{NaOH}\end{array}$ & $\begin{array}{l}9.3 \text { adjusted } \\
\text { by } \mathrm{HCl}\end{array}$ & $1 / 25$ & $60^{\circ} \mathrm{C}$ & $6 \mathrm{~h}$ \\
\hline $\mathrm{NaOH}$ & $0.1 \mathrm{M}$ & & $1 / 50$ & $18^{\circ} \mathrm{C}$ & $18 \mathrm{~h}$ \\
\hline Acetone & aqueous $95 \%$ & & $1 / 50$ & $18^{\circ} \mathrm{C}$ & $18 \mathrm{~h}$ \\
\hline $\mathrm{NH}_{4} \mathrm{Ac}$ & $1 \mathrm{M}$ & $\begin{array}{l}4.8 \text { adjusted } \\
\text { by HAc }\end{array}$ & $1 / 50$ & $18^{\circ} \mathrm{C}$ & $153060120 \mathrm{~min}$ \\
\hline $\mathrm{HXl}$ & $1 \mathrm{M}$ & c. 3 & $1 / 50$ & $18^{\circ} \mathrm{C}$ & $30 \mathrm{~min}$ \\
\hline $\begin{array}{l}\mathrm{HXl-} \\
\mathrm{HAc}\end{array}$ & $\begin{array}{l}1 \mathrm{M} \\
4 \mathrm{M}\end{array}$ & c. 1.8 & $1 / 50$ & $18^{\circ} \mathrm{C}$ & $\begin{array}{l}10204080 \\
160320640 \mathrm{~min}\end{array}$ \\
\hline
\end{tabular}


Table 2. Analytical procedures.

\begin{tabular}{|c|c|c|c|c|}
\hline $\begin{array}{l}\text { CONSTITUENT } \\
\text { DETERMINED }\end{array}$ & $\begin{array}{l}\text { WAVELENGTH } \\
\text { nm }\end{array}$ & SLIT & FLAME & METHOD \\
\hline $\mathrm{Cd}$ & 228.80 & 4 & air- $\mathrm{C}_{2} \mathrm{H}_{2}$ & AAS \\
\hline $\mathrm{Cu}$ & 324.75 & 4 & $»$ & $»$ \\
\hline $\mathrm{Fe}$ & 248.82 & 3 & $»$ & $"$ \\
\hline $\mathrm{K}^{*}$ & 766.49 & 4 & $»$ & $»$ \\
\hline $\mathrm{Li}^{*}$ & 670.78 & 4 & $»$ & " \\
\hline Mn & 279.48 & 3 & $"$ & $»$ \\
\hline $\mathrm{Pb}$ & 283.31 & 4 & $»$ & $»$ \\
\hline $\mathrm{Rb}^{*}$ & 780.02 & 5 & " & " \\
\hline $\mathrm{Zn}$ & 213.86 & 4 & $»$ & » \\
\hline $\mathrm{Ca}^{*}$ & 422.67 & 4 & $\mathrm{~N}_{2} \mathrm{O}-\mathrm{C}_{2} \mathrm{H}_{2}$ & AAS \\
\hline $\mathrm{Al}^{*}$ & $309.27-309.28$ & 4 & $》$ & 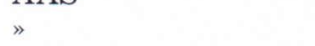 \\
\hline Mg* & 285.21 & 4 & $"$ & " \\
\hline $\mathrm{Hg}$ & 253.60 & & - & AAS Cold vapour \\
\hline $\mathrm{Si}$ & $\mathrm{K}^{* *} 769.90$ & 4 & - & $\begin{array}{l}\text { Visible spectrophoto- } \\
\text { metric }\end{array}$ \\
\hline $\begin{array}{l}\mathrm{PO}_{4} \\
\text { Sedimentary }\end{array}$ & Li 670.78 & 4 & - & 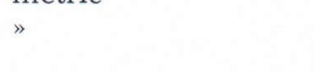 \\
\hline $\begin{array}{l}\text { Chlorophyll } \\
\text { Sedimentary }\end{array}$ & Li 670.78 & 4 & - & $»$ \\
\hline humus & Sr 460.70 & 4 & - & $»$ \\
\hline
\end{tabular}

*) $1 \%$ of $\mathrm{NaCl}$ added for ionization buffer

**) hollow cathode lamp used

AAS instrument PerkinElmer, Model 403

$\mathrm{Mn}, \mathrm{Zn}$ and Si (see Table 2). The HXl and sodium hypochlorite extracts were also analysed for metals. An appropriate matrix was used in standard solutions in the analysis of the extracts. The spectrophotometric determinations were accomplished by AAS. Si was determined as blue molybdosilicic acid using oxalic acid to eliminate $\mathrm{PO}_{4}$ interference (Babko and Pilipenko 1976). $\mathrm{PO}_{4}$ was determined as blue molypdophosphoric complex using ferrous iron and sulphite as the reductant for iron (Babko and Pilipenko 1976). After reduction of iron the sedimentary humus was determined from an aliquot, the solution absorbance being measured at wavelength $460.7 \mathrm{~nm}$ (Table 2). The acetone extract absorbances were measured for sedimentary chlorophyll at wavelength $670.78 \mathrm{~nm}$ (Vallentyne 1955; Moss 1967 and Lorenzen 1967). The absor- bances of the $\mathrm{NaOH}$ extract were measured after coagulating the cations and colloidal iron with $\mathrm{NaSO}_{4}$ by a spectrophotometer (Hitachi, Model 101).

Some comments on geochemical methods

According to Agemian and Chau (1976) many of the trace metals in lake sediments can be extracted by acid digestion and it is assumed that the total leachable elements represent the most characteristic form of elements of interest when studying the sedimentary record for palaeolimnological evidence. The humic matter is generally extracted by $\mathrm{NaOH}$ solution, but an identical result is achieved using $\mathrm{HCl}$ extraction (Schnitzer and Skinner 1968). The $\mathrm{HClO}_{4}$ used in the present study, however, caused partial oxidation and degradation of the 
humic macromolecules (Maximov et al. 1977 and Ruggiero et al. 1980). Nevertheless, the results correlate with those obtained from $\mathrm{NaOH}$ extraction and seem to represent total humus.

Ammonium acetate extract was used to liberate the »exchangeable metals». Thermodynamic calculations show that $\mathrm{NH}_{4} \mathrm{Ac}$ at $\mathrm{pH} 4.8$ will not dissolve iron and manganese oxides, oxyhydroxides or hydroxy complexes (Smith and Martell 1976). Thus the elements released appear to be primarily specifically adsorbed, although $\mathrm{Ca}^{2+}$ will be complexed by the $\mathrm{NH}_{4} \mathrm{Ac}$ extract (Sillen and Martell 1971). Carbonates dissolve, but silicates and organic $\mathrm{C}$ are not attacked. Heavy metals from labile organic complexes (e.g. humic acid complexes) are also dissolved to some extent by the $\mathrm{NH}_{4} \mathrm{Ac}$ extract (Slavek et al. 1982). The hydroxylammonium chloride extract dissolves oxidized forms of Mn (Chao 1972) but does not attack the Fe oxyhydroxides and oxides. The 1 M hydroxylammonium chloride with $4 \mathrm{M}$ acetic acid dissolves poorly crystallized $\mathrm{Fe}$ oxyhydroxides and oxides (Chester and Hughes 1967). It also attacks siliceous material, especially during prolonged extraction. Metals from labile organic complexes dissolve to some extent. Sodium hypochlorite at pH 9.3 liberates the heavy metals complexed by organic matter (Gibbs 1973). Analytical accuracy tends to be better than \pm 5 per cent.

\section{Mineralogy}

For qualitative determination of the clay minerals and residual rock-forming minerals, 28 X-ray diffraction analyses were performed on the fine-grained $(<20 \mu)$ material from different parts of the sedimentary column (see Fig. 2), using a Philips X-ray diffractometer with $\mathrm{CuK}$ radiation (cf. Uusinoka 1975, p. 13).

\section{Results and discussion}

The content of acid-digested elements, $\mathrm{Ca}, \mathrm{Li}, \mathrm{Mg}, \mathrm{Al}$ and, especially, Fe, is elevated in the lowermost banded sulphide clay. As indicated by loss on ignition, sedimentary, chlorophyll and humus determinations, the productivity of Lake Iidesjärvi is initiated immediately after its isolation. With the exception of $\mathrm{Fe}$, the content of elements increases, too (see Figs 3-6). Thereafter, as soon as the sedimentation of the brown detritus gyttja is interrupted by the pale grey gyttja layer (see Fig. 2) the organic matter decreases together with a temporary increase in the content of $\mathrm{Li}, \mathrm{Al}, \mathrm{Mg}, \mathrm{Ca}, \mathrm{Zn}$ and $\mathrm{PO}_{4}$. First the $\mathrm{K}$ and $\mathrm{Rb}$ contents reach a minimum whereas the organic matter increases further to a maximum as the sedimentation of the brown fine detritus gyttja continues. At this point the $\mathrm{Mn}$ and $\mathrm{Cu}$ contents are elevated, too, and a slight decrease is shown in the $\mathrm{Fe}$ content. The organic matter then increases again together with the elevated content of most of the elements studied. At a depth of c. 270$230 \mathrm{~cm}$, the organic content decreases once more. The $\mathrm{Cu}$ content correlates with the organic matter, showing, however, no depressions. The humus content (Fig. 4) shows a maximum at a depth of $170 \mathrm{~cm}$ as does the NAP curve (see Alhonen 1981). The $\mathrm{Li}, \mathrm{K}$ and $\mathrm{Rb}$ contents are elevated at a depth of $220-190 \mathrm{~cm}$, and the Mn content at a depth of $190 \mathrm{~cm}$.

The $\mathrm{Al}, \mathrm{PO}_{4}, \mathrm{Zn}, \mathrm{Cu}$ and $\mathrm{Li}$ contents increase in the topmost part of the lithostratigraphy. The elevated $\mathrm{Zn}$ and $\mathrm{Cu}$ contents seem to originate from anthropogenic enrichment whereas the $\mathrm{Al}$ content may reflect cultural acidification by $\mathrm{SO}_{\mathrm{x}}$ and $\mathrm{NO}_{\mathrm{x}}$ compounds emitted during fossil combustion in local industry or transported by long-range acid rain. As a consequence of acidification $\mathrm{Al}$ is mobilized and transported to the lakes 


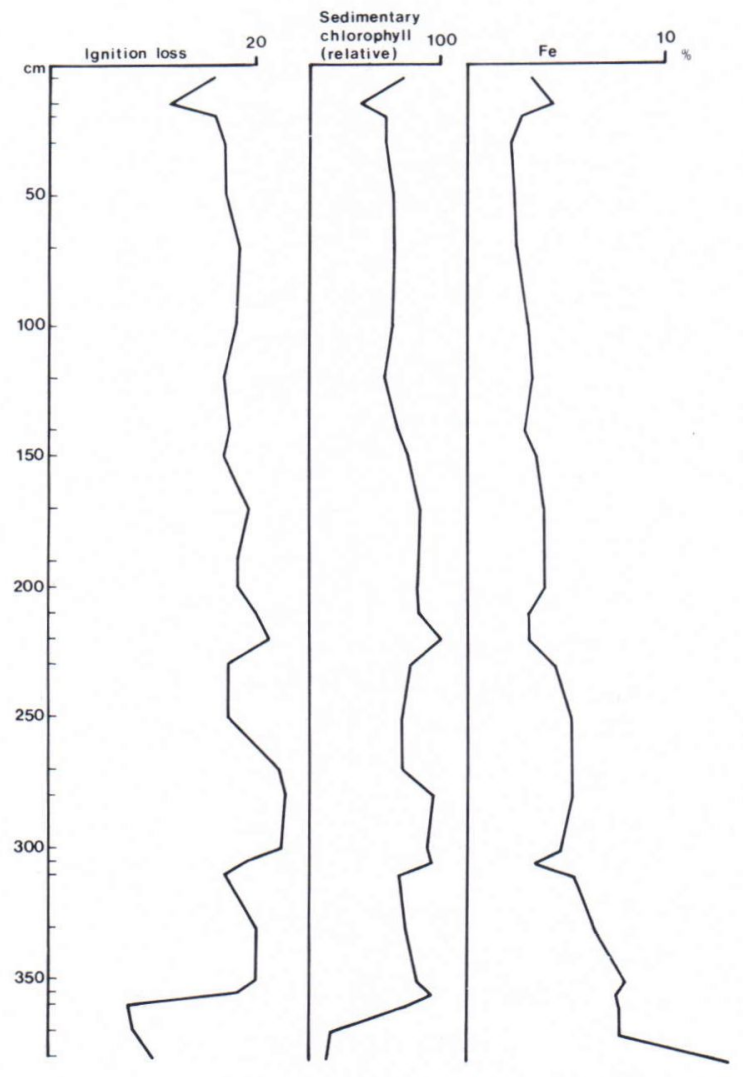

Fig. 3. Lake Iidesjärvi: vertical distribution of loss on ignition, sedimentary chlorophyll and $\mathrm{Fe}$ in the investigated core.

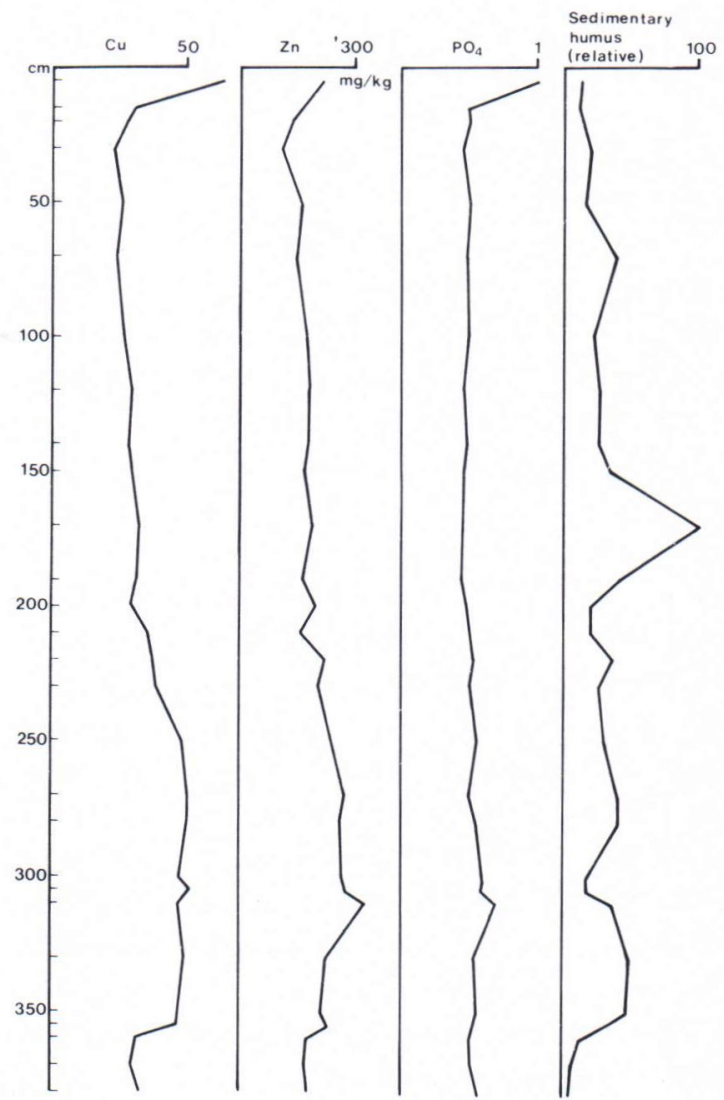

Fig. 4. Lake Iidesjärvi: vertical distribution of $\mathrm{Cu}$, $\mathrm{Zn}, \mathrm{PO}_{4}$ and sedimentary humus in the investigated core.
(Cronan and Schofield 1979 and Johnson 1979).

Anthropogenic enrichment of heavy metals such as $\mathrm{Cd}, \mathrm{Cu}, \mathrm{Hg}, \mathrm{Pb}$ and $\mathrm{Zn}$ is clearly seen in the uppermost part (from 20 to $1 \mathrm{~cm}$ ) of the shorter core (Figs 7 and 8), which was sampled for analysis with a denser sample interval than the longer one. The contents of $\mathrm{Cu}, \mathrm{Pb}$ and $\mathrm{Zn}$ during the pollution development of Lake Iidesjärvi coincide more closely with those from heavily industrialized areas of southern Lake Michigan (Leland et al. 1973) and Lake Erie (Nriagu et al. 1979) than with those from Kuopio (Salminen 1976 and 1979) and Quebec (Ouellet and Jones 1982). The primary cause of anthropogenic enrichment of $\mathrm{Cd}, \mathrm{Cu}, \mathrm{Hg}, \mathrm{Pb}$ and $\mathrm{Zn}$ is industrial development around Tampere since the beginning of this century, especially since the 1950s.

The increase of Mn content in the topmost part of the core (Fig. 9) may be due to diffusion and oxidative or organic fixation of the $\mathrm{Mn}^{2}+$ released after being reduced as a consequence of cultural eutrophication of Lake Iidesjärvi. It is also indicated by the increase of organic matter and $\mathrm{PO}_{4}$ content in the uppermost lithostratigraphy as dis- 
Stratigraphical studies on Lake Iidesjärvi sediments. Part II. . . 147

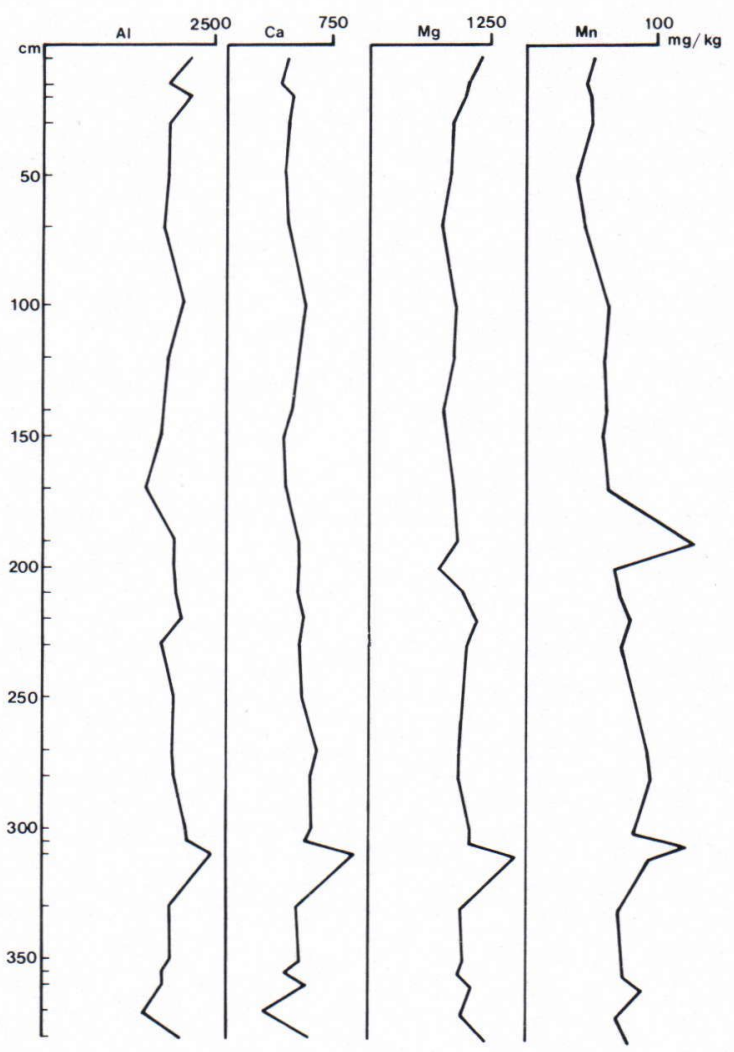

Fig. 5. Lake Iidesjärvi: vertical distribution of $\mathrm{Al}, \mathrm{Ca}, \mathrm{Mg}$ and $\mathrm{Mn}$ in the investigated core.

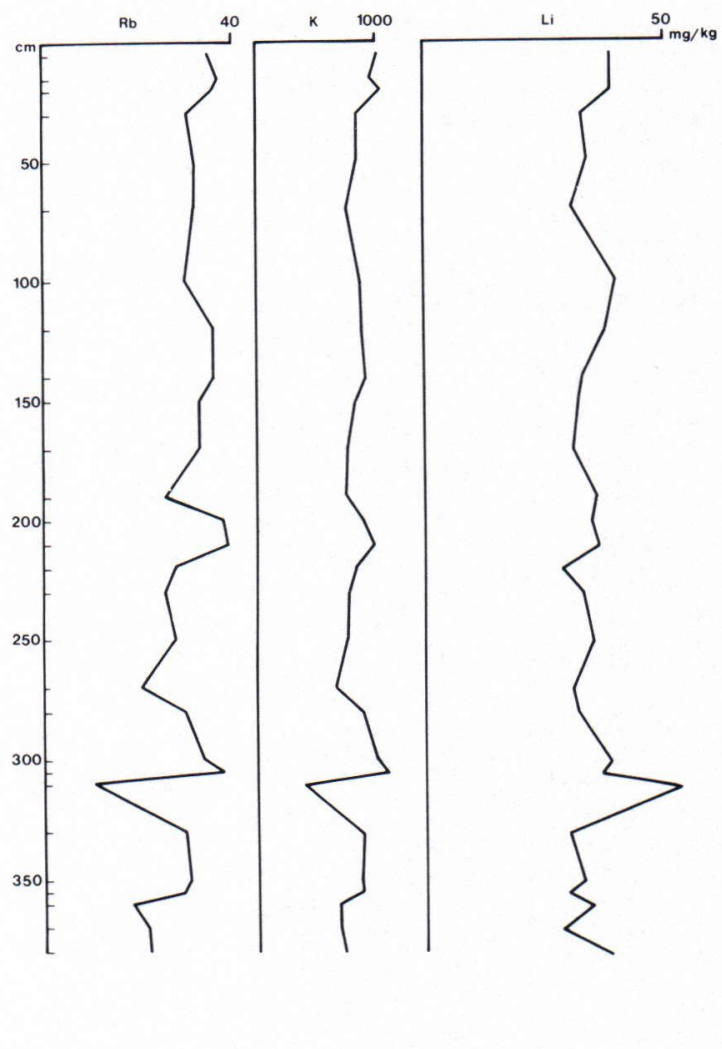

Fig. 6. Lake Iidesjärvi: vertical distribution of $\mathrm{Rb}, \mathrm{K}$ and $\mathrm{Li}$ in the investigated core. cussed earlier by Alhonen (1979, pp. 21-22) and others. However, the increase of $\mathrm{Mn}$ is not so pronounced as in a Norwegian fjord discussed in a study by Skei and Paus (1979).

Some features caused by the cultural eutrophication of Lake Iidesjärvi can be discovered by extraction studies using ammonium acetate $\left(\mathrm{NH}_{4} \mathrm{Ac}\right)$ and hydroxylammonium chloride plus acetic acid (HXlHAc). The results show that the amount of loosely bound $\mathrm{HXl}-\mathrm{HAc}$-extractable $\mathrm{Si}$ is lower in the upper sediment sequence $(12-100 \mathrm{~cm})$ than in the sequence beneath it $(110-170 \mathrm{~cm})$. The same is shown by the
HXl-HAc and $\mathrm{NH}_{4} \mathrm{Ac}$-extractable $\mathrm{Fe}$, which correlates with Si (Fig. 10). During short extraction the $\mathrm{HXl}-\mathrm{HAc}$-soluble Si released is evidently loosely bound, but during longer extraction (from 40 to 640 minutes) $\mathrm{Si}$ is withdrawn from diatom cells (see Lewin 1961 and Jones and Handreck 1963) and clay minerals as well. The elevated $\mathrm{Si}$ solubility during 160-320 minutes' extraction coincides with the elevated $\mathrm{Zn}$ solubility, which indicates that the solubilized elements originate primarily from clay minerals (Figs 11-14). The correlation between $\mathrm{HCl}$ $\mathrm{HAc}$-soluble $\mathrm{Si}, \mathrm{Fe}$ and $\mathrm{Ca}$ indicates that 


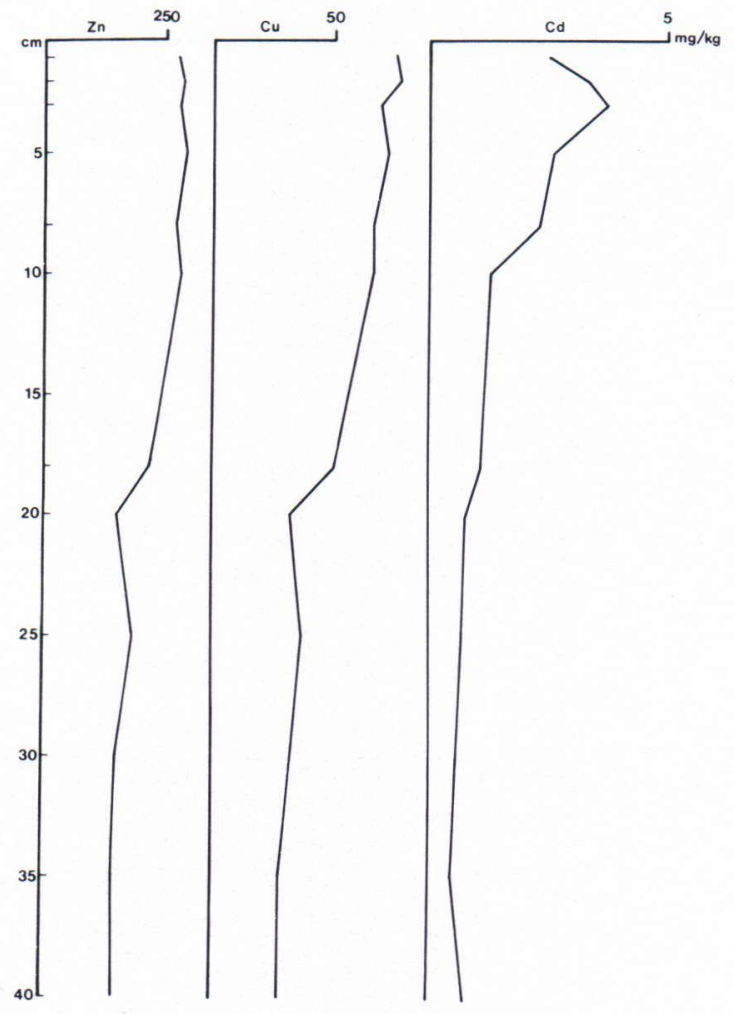

Fig. 7. Lake Iidesjärvi:vertical distribution of $\mathrm{Zn}$, $\mathrm{Cu}$ and $\mathrm{Cd}$ in the topmost $40 \mathrm{~cm}$ of the investigated core.

these elements interact chemically in the sediments of Lake Iidesjärvi (cf. Morgan and Stumm 1963). The amount of $\mathrm{NH}_{4} \mathrm{Ac}$-soluble $\mathrm{Si}$ is low and its variation great, which indicates weak adsorption of $\mathrm{Si}$ in the samples. In contrast, $\mathrm{Si}$ is strongly associated with the surface layer owing to freshly precipitated natural oxyhydroxide precipitates, and $\mathrm{Ca}, \mathrm{Mg}, \mathrm{Mn}$ and $\mathrm{Zn}$ are adsorbed (Vuorinen and Carlson 1983).

The depletion of loosely bound Si in the upper sediment sequence might thus be due to increased diatom uptake of dissolved Si from lake water as a result of cultural eutrophication caused by anthropogenic input of $\mathrm{PO}_{4}$ (Powers and Ayers 1967;
Schelske and Stroermer 1971). The fluctuation in $\mathrm{K}, \mathrm{Mg}$, Ca and $\mathrm{Fe}$ solubilities seems to reflect the pollution development of Lake Iidesjärvi in its sediment sequence (Figs. 15-18). As a rule, the amount of $\mathrm{NH}_{4} \mathrm{Ac}$-extractable elements considerably decreases during extraction, which is considered to indicate that the elements primarily exist as specifically adsorbed on the particulate material.

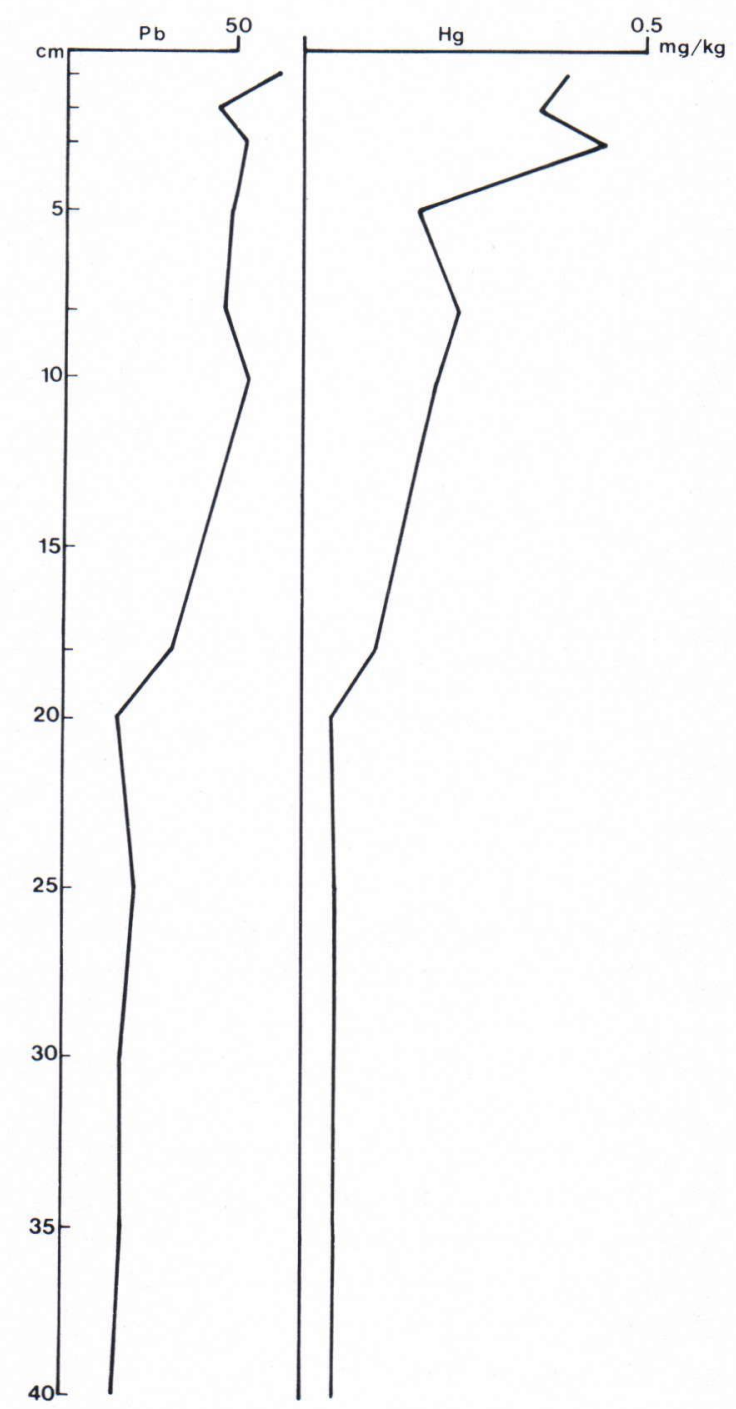

Fig. 8. Lake Iidesjärvi: vertical distribution of $\mathrm{Pb}$ and $\mathrm{Hg}$ in the topmost $40 \mathrm{~cm}$ of the investigated core. 


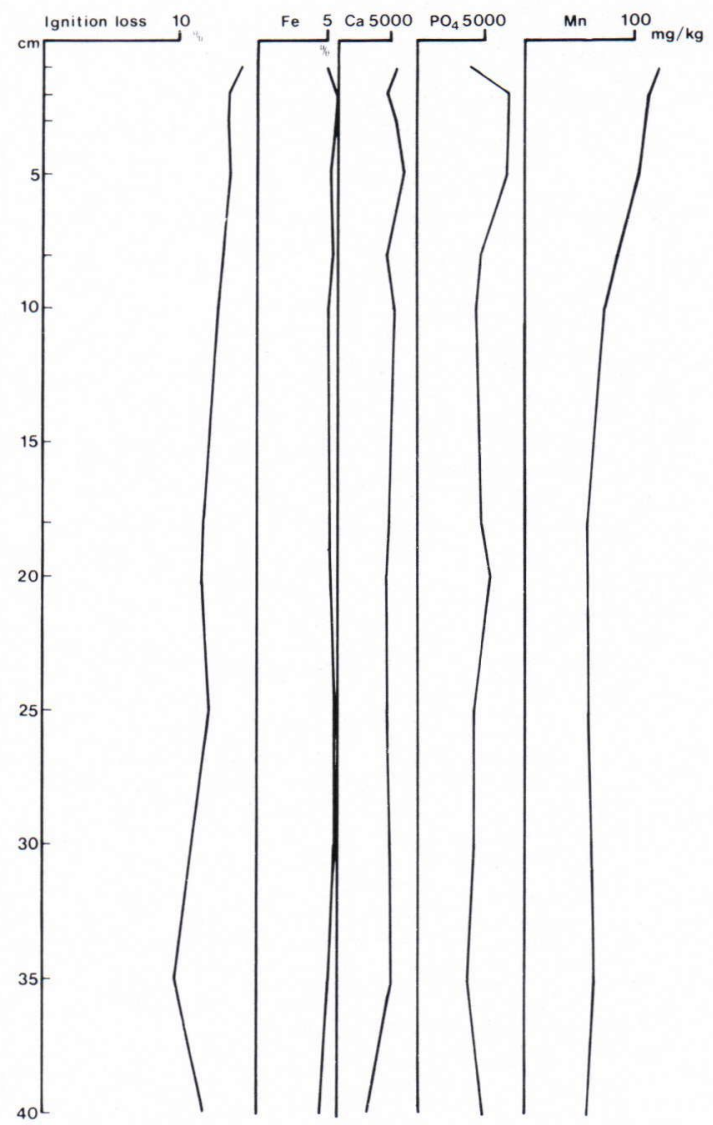

Fig. 9. Lake Iidesjärvi: vertical distribution of loss on ignition $\mathrm{Fe}, \mathrm{Ca}, \mathrm{PO}_{4}$ and $\mathrm{Mn}$ in the topmost $40 \mathrm{~cm}$ of the investigated core.

The adsorption order of the elements is calculated as the percentage extracted by $\mathrm{NH}_{4} \mathrm{Ac}$ solution during the shortest extraction time $(15 \mathrm{~min})$ of the total amount extractable, using average elemental contents of sample-intervals of 12 to $170 \mathrm{~cm}$. The order was Mg, Ca, Mn, K, Zn, Cu (Fig. 19). This corresponds to the prevailing forms of loosely bound elements. $\mathrm{Mg}$ and $\mathrm{Ca}$ exist as cationic adsorbed forms as, to a slight lesser extent, do $\mathrm{Mn}, \mathrm{K}$ and $\mathrm{Zn}$. In contrast, some of the Fe was present in colloidal form in the sediments and oxidized partly to oxyhydroxides during the preparation of
Fe HXI-HAC
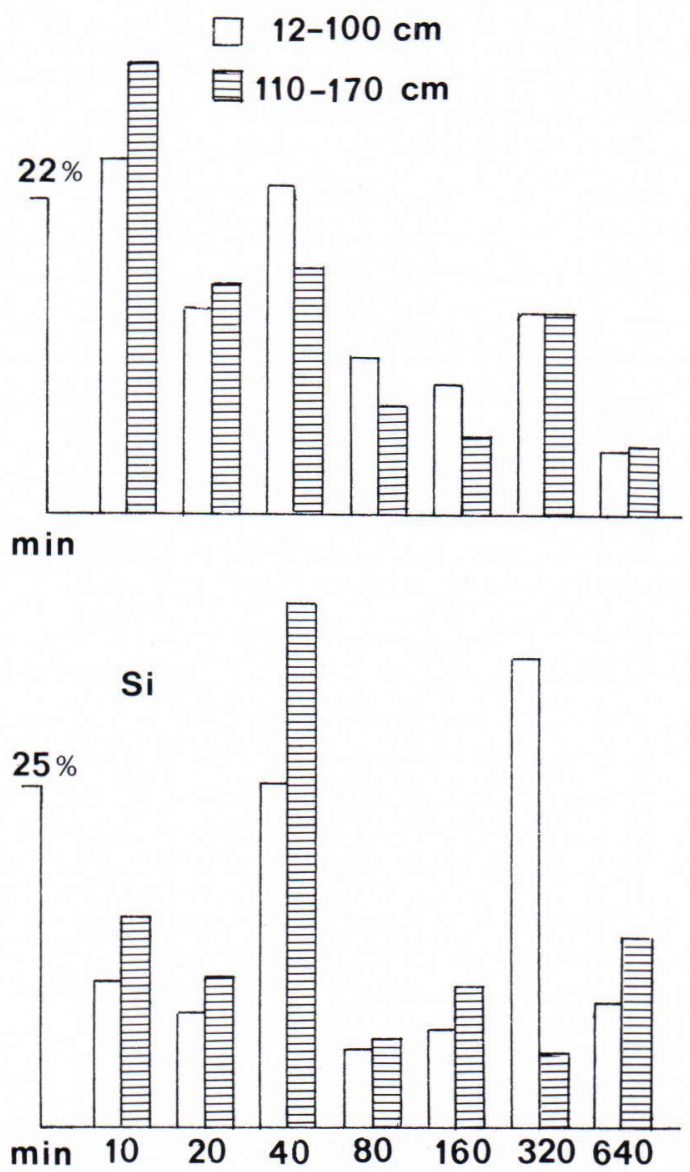

Fe $\quad \mathrm{NH}_{4} \mathrm{Ac}$

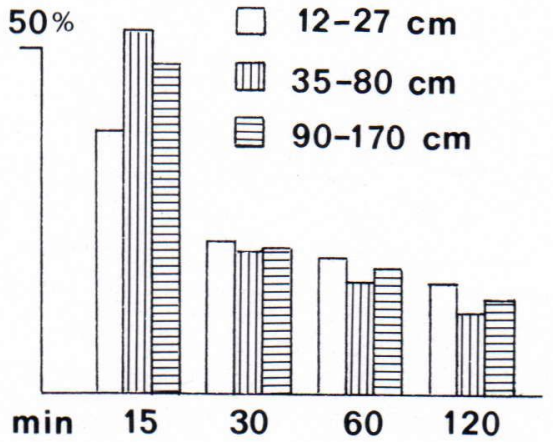

Fig. 10. Lake Iidesjärvi: Fe and Si-HXl-HAc and $\mathrm{NH}_{4}^{-} \mathrm{Ac}$ dissolution (\% of total soluble) from upper and lower parts of the investigated core during different extraction intervals. 

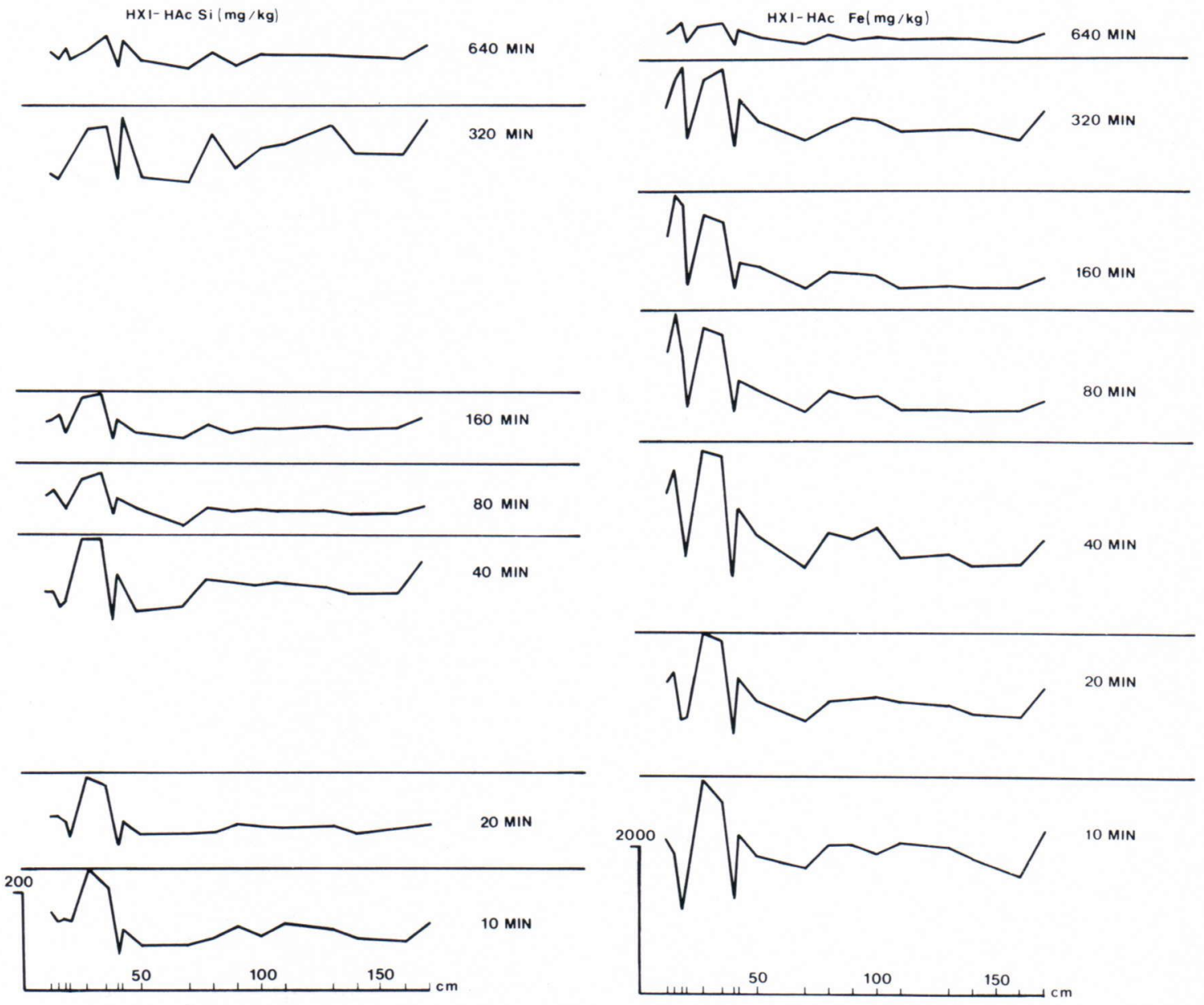

Fig. 11. Lake Iidesjärvi: HXl-HAc-extractable Si in the investigated core during different extraction intervals.

Fig. 12. Lake Iidesjärvi: HXl-HAc-extractable Fe in the investigated core during different extraction intervals.

40 MIN

20 MIN

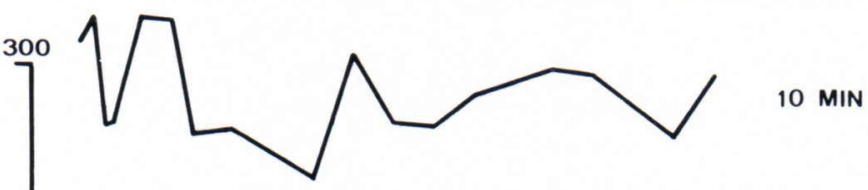

Fig. 13. Lake Iidesjärvi: HXlHAc-extractable $\mathrm{Ca}$ in the investigated core during different extraction intervals. 
HXI-HAC Zn (mg/kg)
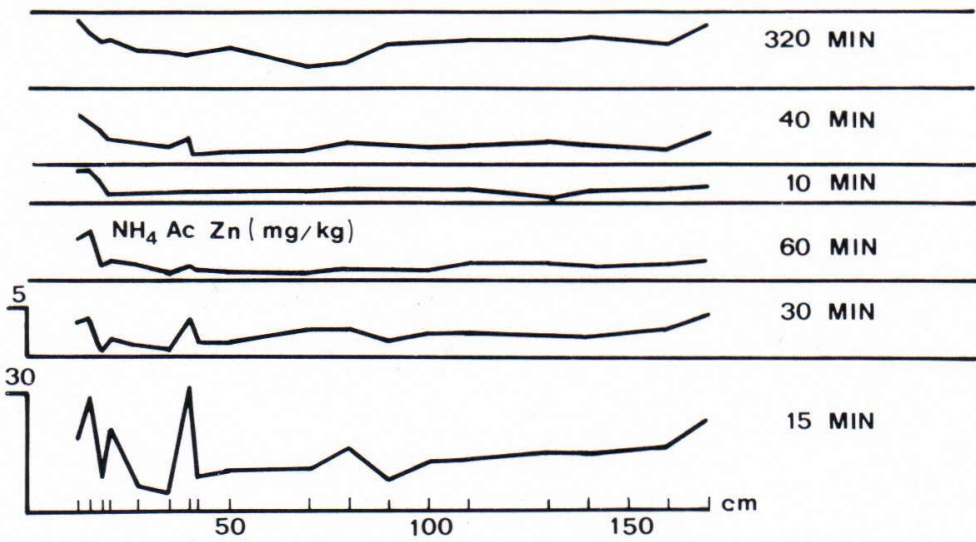

Fig. 14. Lake Iidesjärvi: $\mathrm{HXl}-\mathrm{HAc}$ and $\mathrm{NH}_{4} \mathrm{Ac}$-extractable $\mathrm{Zn}$ in the investigated core during different extraction intervals.

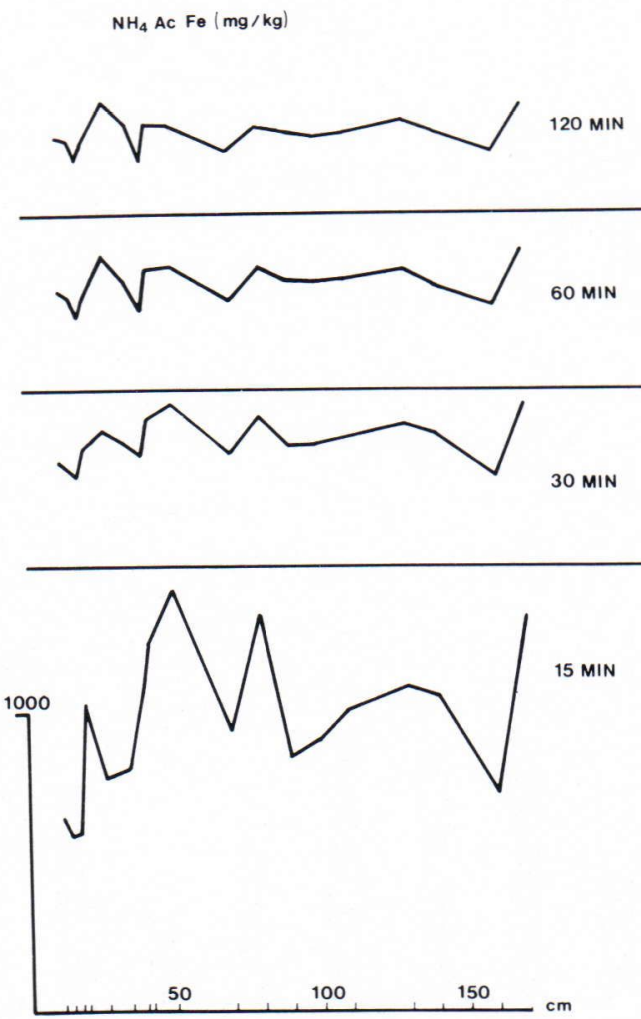

Fig. 15. Lake Iidesjärvi: $\mathrm{NH}_{4}$ Ac-extractable $\mathrm{Fe}$ in the investigated core during different extraction intervals.

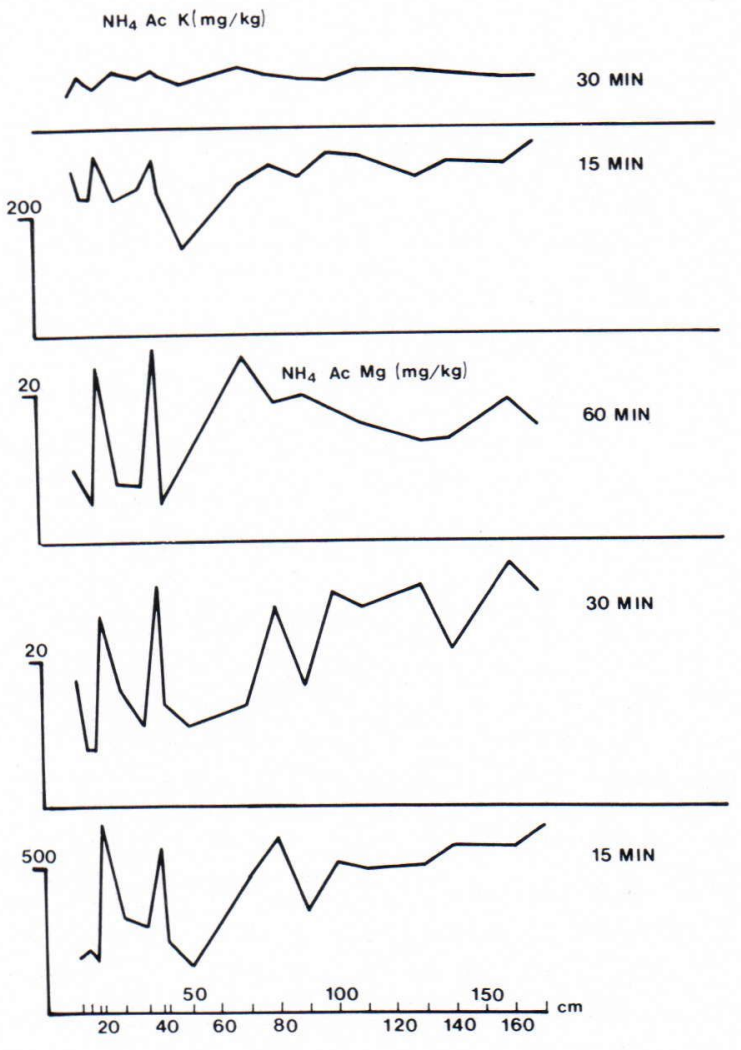

Fig. 16. Lake Iidesjärvi: $\mathrm{NH}_{4}$ Ac-extractable $\mathrm{K}$ and $\mathrm{Mg}$ in the investigated core during different extraction intervals. 


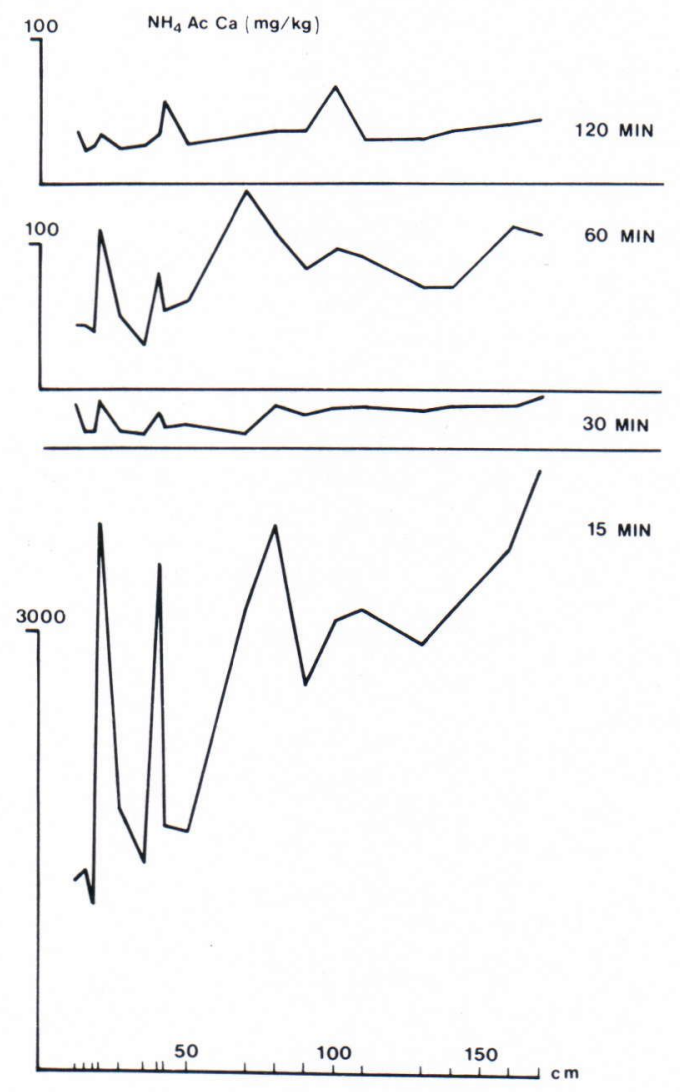

Fig. 17. Lake Iidesjärvi: $\mathrm{NH}_{4} \mathrm{Ac}$-extractable $\mathrm{Ca}$ in the investigated core during different extraction intervals.

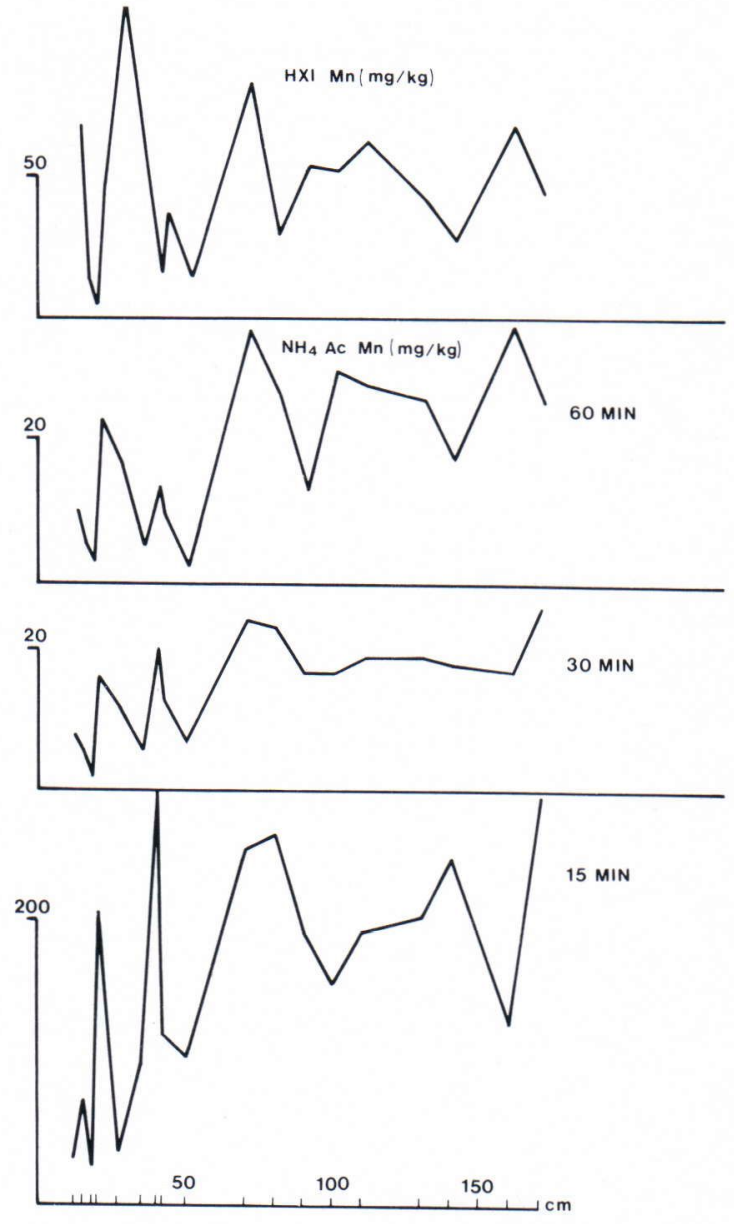

Fig. 18. Lake Iidesjärvi: $\mathrm{HXl}$ and $\mathrm{NH}_{4} \mathrm{Ac}-\mathrm{ex}-$ tractable $\mathrm{Mn}$ in the investigated core during different extraction intervals.

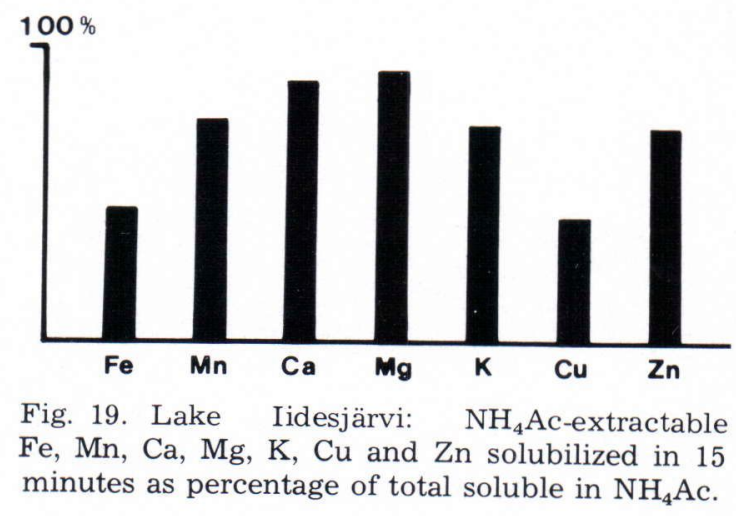

Fig. 19. Lake Iidesjärvi: $\mathrm{NH}_{4}$ Ac-extractable $\mathrm{Fe}, \mathrm{Mn}, \mathrm{Ca}, \mathrm{Mg}, \mathrm{K}, \mathrm{Cu}$ and $\mathrm{Zn}$ solubilized in 15 minutes as percentage of total soluble in $\mathrm{NH}_{4} \mathrm{Ac}$. the samples. $\mathrm{Cu}$ associates mainly with organic matter (see also Presley et al. 1972; Tessier, Cambell and Bisson 1979).

To elucidate the character of the humic substances in the lithostratigraphy of Lake Iidesjärvi the absorbance of $\mathrm{NaOH}$ extracts of humic matter diluted 10 fold were measured at wavelengths of 430, 465, 490, 550, 600 and $665 \mathrm{~nm}$, and absorption curves versus wavelength were constructed (Fig. 20). The slope of the curves is related to the condensa- 
tion degree of the humic acids (Pauli 1967). A low slope is characteristic of highly condensed humic acids and a steep one of slightly condensed fulvic acids. The study showed that the fulvic acid component and the humus content increases with sediment depth, possibly because of the degradation of humic macromolecules in the sedimentary environment, e.g. by micro-organisms (see Anderson 1979). It is a subject worth studying further.

The relative order of elements solubilized by different extracts was calculated to evaluate the binding of elements by different sediment constituents. The element content digested in acid was taken as the total content digested in acid was taken as the total content. The appropriate percentage subdivision was calculated for each element after subtracting the other extractable element contents (Fig. 21). The following order was obtained:

Elements

extracted by

bound by

Silicate-clay

matter acid digestion

Fe oxyhydroxides

and oxides

Mn oxides

Adsorption

Organic matter

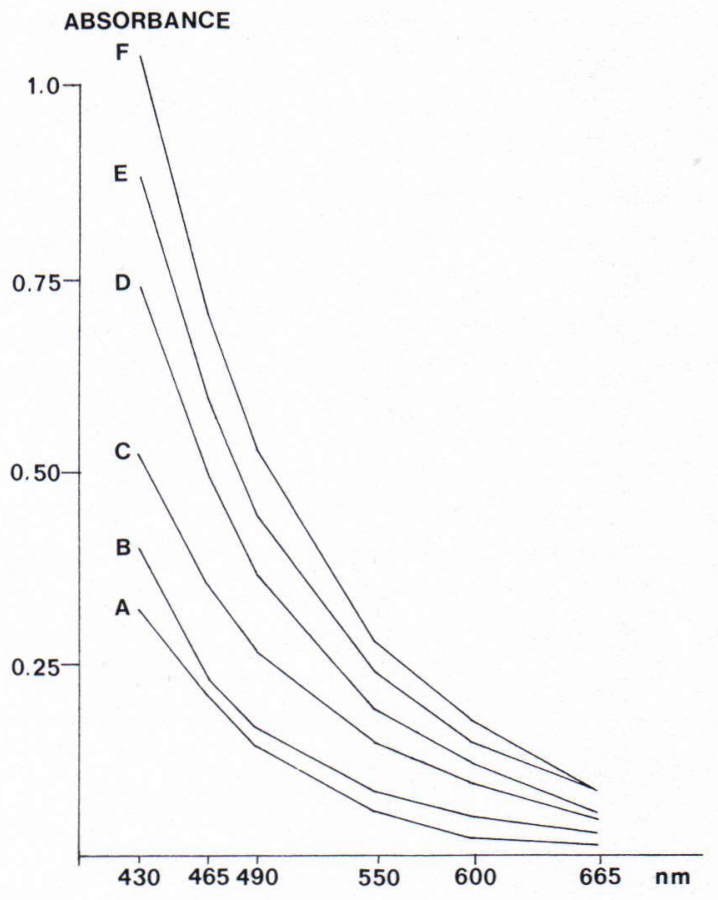

Fig. 20. Lake Iidesjärvi: the humic compound extract absorbances vs. wavelength (see discussion).

Order of binding

$\mathrm{Zn} \mathrm{Fe} \mathrm{K} \mathrm{Mg} \mathrm{Mn} \mathrm{Ca} \mathrm{Cu}$

$\mathrm{Cu} \mathrm{Fe} \mathrm{Zn} \mathrm{Ca} \mathrm{Mn}$

$\mathrm{Mn} \mathrm{Ca} \mathrm{Zn}$

$\mathrm{Ca} \mathrm{K} \mathrm{Mg} \mathrm{Cu} \mathrm{Mn} \mathrm{Zn} \mathrm{Fe}$

$\mathrm{Cu} \mathrm{Mn} \mathrm{Zn}$

In general, the mineralogical composition of the sediments was not dissimilar to that of the Finnish argillaceous sediments as a whole (see. e.g. Soveri 1956; Sippola 1974; Gardemeister 1975 and Alhonen et al. 1978). As to the residual, fine-grained and unweathered rock-forming minerals, quartz, plagioclase, potassic feldspar and amphibole were present in all samples throughout the

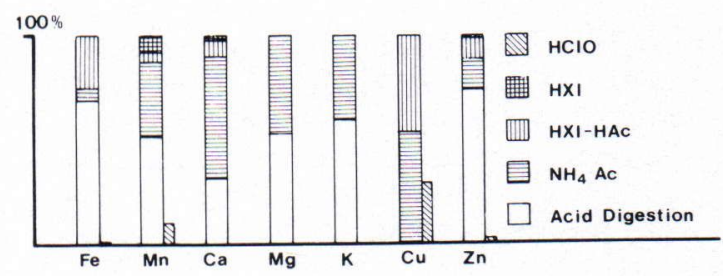

Fig. 21. Lake Iidesjärvi: $\mathrm{Fe}, \mathrm{Mn}, \mathrm{Ca}, \mathrm{Mg}, \mathrm{K}$. $\mathrm{Cu}$ and $\mathrm{Zn}$ as proportional percentages extracted by different procedures (see discussion). 
sedimentary sequence of Lake Iidesjärvi, with quartz being the dominant mineral and amphibole and potassic feldspar the least abundant. Mica and illite, in most samples both di and trioctahedral types, and chlorite were present in varying amounts in all the samples. Vermiculite, too, was found throughout almost the whole lithostratigraphy of the lake as were the mixed-layer minerals chlorite-illite and illite-vermiculite. Identifiable amounts of smectite or kaolinite were not found in the samples analysed.

The presence of illite, chlorite and vermiculite, both as such and as members of mixed-layer minerals, indicates some progress of weathering phenomena before and during sedimentation of the sedimentary material derived from glacial drift eroded from bedrock situated, according to the orientation of the glacial striae, in an exceptionally wide sector, from Lake Iidesjärvi to N-SW (see Virkkala 1962). The composition of the bedrock varies conspicuously, the granitoids and various micaceous schists and gneisses, however, being dominant (see Matisto 1961).

\section{References}

Agemian, H. and Chau, A. S. Y., 1976. Evaluation of extraction techniques for determination of metals in aquatic sediments. Analyst 101, $761-767$.

Alhonen, P., 1979. The sedimentary record of the cultural eutrophication and pollution of lakes in Finland. Arch. Hydrobiol. 86, 13-26.

Alhonen, P., 1981. Stratigraphical studies on Lake Iidesjärvi sediments. Part 1. Environmental changes and palaeolimnological development. Bull. Geol. Soc. Finland 53, 97-107.

Alhonen, P., Eronen, M., Nunez, M., Salomaa, $R$. and Uusinoka, R., 1978. A contribution to Holocene shore displacement and environmental development in Vantaa, South Finland:
The amount of clay minerals is closely correlated with the amount of exchangeable ions, such as potassium and magnesium, in soils. Owing to its high cation exchange capacity, vermiculite is particularly closely correlated with the contents of exchangeable cations (see e.g. Sippola 1974). In a sedimentation basin, the presence of clay minerals with extractable magnesium, iron and potassium might thus be able to create conditions leading to minero-eutrophy of a lake. Vermiculite has been found in the bottom deposits of Lake Iidesjärvi, since the lower part of the column studied, and its presence both as such and as a member of mixed layer illite-vermiculite, is somewhat higher than in most other areas studied ( $c f$. Gardemeister 1975 and Alhonen et al. 1978). This is probably due to the micarich bedrock in the environment and the relatively easy wheatherability of biotite to the "hydromica» stage, i.e. biotite-vermiculite.

Acknowledgement. The financial aid from the Maj and Tor Nessling Foundation to Professor Pentti Alhonen is gratefully acknowledged.

the stratigraphy of Lake Lammaslampi. Bull. Geol. Soc. Finland 50, 69-79.

Anderson, D. W., 1979. Processes of humus formation and transformation in soils of the Canadian Great Plains. J. Soil Sci. 30, 77-84.

Babko, A. K. and Pilipenko A. T., 1976. Photometric Analysis. Methods of Determining Non-metals. Moscow, Mir Publishers. 374 pp.

Chao, T. T., 1972. Selective dissolution of manganese oxides from soils and sediments with acidified hydroxylamine hydrochloride. Soil Sci. Soc. Am. Proc. 36, 764-768.

Chester, R. and Hughes, M. J., 1967. A chemical technique for the separation of ferro-manganese minerals, carbonate minerals and adsorbed trace elements from pelagic sediments. Chem. Geol. 2, 249-262. 
Cronan, C. S. and Schofield, C. L., 1979. Aluminium leaching response to acid precipitation: effects on high elevation watersheds in the Northeast. Science 204, 304-306.

Gardemeister, R., 1975. On engineering-geological properties of fine-grained sediments in Finland. Technical Research Centre of Finland, Building Technology and Community Development. Publ. 9. 91 p.

Gibbs, R. J., 1973. Mechanisms of trace metal transport in rivers. Science 180, 71-73.

Johnson, N. M., 1979. Acid rain: neutralization within the Hubbart Brook ecosystem and regional implication. Science 204, 497-499.

Jones, L. H. P. and Handreck, K. A., 1963. Effects of iron and aluminium on silica in solution in soils. Nature 198. 852-853.

Leland, H. V., Shukla, S. S. and Shimp, N. F., 1973. Factors affecting lead and other trace elements in sediments of southern Lake Michigan. In: Singer, P. C. (ed.) Trace metals and metalorganic interactions in natural waters. 89129. Ann Arbor Sci. Publ. Michigan.

Lewin, J. C., 1961. The dissolution of silica from diatom walls. Geochim. Cosmochim. Acta 21, $182-198$.

Lorenzen, C. J., 1967. Determination of chlorophyll and pheopigments: spectrophotometric equations. Limnol. Oceanogr. 12, 343-346.

Mackereth, F. J. H., 1966. Some chemical observations on post-glacial lake sediments. Phil. Trans. B. 250, 165-213.

Matisto, A., 1961. Suomen geologinen kartta Geological Map of Finland, Kallioperäkartta Pre-Quaternary Rocks of Finland. Lehti Sheet 2123 Tampere. Geologinen tutkimuslaitos.

Maximov, O. B., Shvets, T. V. and Elkin, Yu. N., 1977. On permanganate oxidation of humic acids. Geoderma 19, 63-78.

Moss, B., 1967. A note on the estimation of chlorophyll a in freshwater algal communities. Limnol. Oceanogr. 12, 340-342.

Nriagu, J. O., Kemp, A. L. W., Wong, H. K. T. and Harper, N., 1979. Sedimentary record of heavy metal pollution in Lake Erie. Geochim. Cosmochim. Acta 43, 247-258.

Pauli, F. W., 1967. Soil Fertility. A Biodynamic Approach. 133-137. Adam Hilger Ltd., London.

Powers, C. F. and Ayers, J. C., 1967. Water quality and eutrophication trends in southern Lake Michigan. Univ. Michigan Gt. Lakes Res. Div., Spec. Rep. 30, 142-178.
Presley, B. J., Kolodny, Y., Nissenbaum, A. and Kaplan, I. R., 1972. Early diagenesis in a reducing fjord, Saanich Inlet, British Columbia. - II. Trace element distribution in interstitial water and sediment. Geochim. Cosmochim. Acta 36, 1073-1090.

Ouellet, M. and Jones, H. G., 1983. Paleolimnological evidence for the long-range atmospheric transport of acidic pollutants and heavy metals into the Province of Quebec, eastern Canada. Can. J. Earth Sci. 20, 23-36.

Ruggiero, P., Interesse, F. S., Cassidei, L. and Sciacovelli, O., 1980. H NMR spectra of humic and fulvic acids and their peracetic oxidation products. Geochim. Cosmochim. Acta 44, 603-609.

Salminen, R., 1976. Contamination of stream and lake sediments in Kuopio urban area. J. Geochim. Expl. 5, 406-409.

Salminen, R., 1979. Raskasmetallisaasteet rantasedimenteissä. Summary: Heavy metal pollution in littoral sediments. Geol. Surv. Finland, Rep. Invest. 34, 85-92.

Schelske, C. L. and Stroermer, E. F., 1971. Eutrophication, silica depletion and predicted changes in algal quality in Lake Michigan. Science 173, 423-424.

Schnitzer, M. and Skinner, S. I. M., 1968. Alkali versus acid extraction of soil organic matter. Soil Sci. 105, 392-396.

Sillen, L. G. and Martell, A. E., 1964. Stability constants of metal-ion complexes. Chem. Soc. Spec. Publ. 17. London.

Sippola, J., 1974. Mineral composition and its relation to texture and to some chemical properties in Finnish subsoils. Ann. Agr. Fennicae 13, 169-234.

Skei, J. and Paus, P. E., 1979. Surface metal enrichment and partioning of metals in a dated sediment core from a Norwegian fjord. Geochim. Cosmochim. Acta 43, 239-246.

Slavek, J., Wold, J. and Pickering, W. F., 1982. Selective extraction of metal ions associated with humic acids. Talanta 29, 743-749.

Smith, R. M. and Martell, A. E., 1976. Critical Stability Constants, Vol. 1-4. Plenum Press. New York, N. Y. 583 p.

Soveri, U. 1956 The mineralogical composition of argillaceous sediments of Finland. Ann. Acad. Sci. Fennicae A III 48, 32 p.

Tessier, A., Cambell, P. G. C. and Bisson, M., 1979. Sequential extraction procedure for the speciation of particulate trace metals. Anal. Chem. $51,844-851$. 
Uusinoka, R., 1975. A study of the composition of rock-gouge in fractures of Finnish Precambrian. Comment. Phys.-Math. 45, 101 p.

Vallentyne, $J$. R., 1955. Sedimentary chlorophyll determination as a paleobotanical method. Can. J. Bot. 33, 304-313.

Virkkala, K., 1962. Suomen geologinen kartta Geological Map of Finland, Lehti - Sheet 2123 Tampere, Maaperäkartan selitys - Explanation to the Map of Superficial Deposits. Geologinen tutkimuslaitos, $70 \mathrm{p}$.
Vuorinen, A. and Carlson, L., 1983. Interaction of silica and iron in formation of natural iron oxyhydroxide precipitates. 5 th Meeting of the European Clay Groups, Pragua, 175.

Weber, W. J. Jr. and Stumm, W., 1965. Formation of a silicatoiron (III) complex in dilute aquous solution. J. Inorg. Nucl. Chem. 27, 237-239.

Manuscript received, April 26, 1983. 